\title{
American Sectionalism in the British Mind, 1832-1863
}

Review Number: 2227

Publish date: Thursday, 22 March, 2018

Author: Peter O'Connor

ISBN: 9780807168158

Date of Publication: 2017

Price: $£ 35.00$

Pages: 280pp.

Publisher: Louisiana State University Press

Publisher url: https://lsupress.org/books/detail/american-sectionalism-in-the-british-mind-1832-1863/

Place of Publication: Baton Rouge, LA

Reviewer: David Tiedemann

In the last year several books appeared focused on the United States in the world that seek to combine a study of intellectual history, popular culture and politics in a long breath of the 19th century. The most notable, and excellent, examples of this fusion are Marc-William Palen's The 'Conspiracy' of Free Trade: The Anglo-American Struggle over Empire and Economic Globalisation, 1846-1896, and Axel Körner's America in Italy: The United States in the Political Thought and Imagination of the Italian Risorgimento, 1763-1865.(1) Both works have at their core a discussion of a particular idea, protectionism and free trade in the former case, and the example of the American Revolution in Italy the latter. Each book examines these discussions both intellectually and popularly with great effect. Körner and Palen are able to show both the contours in and understandings of ideas about the United States, and these notions popular and political applications. America in Italy particularly ranges across several fields focusing on political thinkers and their writing, but also dealing with the history of opera and other theatre set in the United States.

Peter O'Connor's American Sectionalism in the British Mind, 1832-1863 is an excellent addition to this existing fusion of intellectual and popular history of the United States in the world. American Sectionalism examines British ideas about regional cultural and political divisions within the United States before the Emancipation Proclamation. O'Connor offers a totally new way to understand British perceptions of sectionalism, beyond a merely political phenomenon of North versus South divide; rather Britons had more nuanced ways of seeing the United States. The book highlights how British travelogue writers were particularly interested in New England as a regionally distinct part of the country. Similarly these authors stressed the country's ethnic divisions. New York City was, for many British visitors to the United States, much more ethnically heterogeneous than the South or New England. Divisions then, were much more cultural and ethnic than political.

O'Connor also argues British writers on the United States saw slavery a more national and less factional issue than Americans. Persistent racism in the North, combined with an acceptance of Southern paternalist dogma around slaveholding, meant that slavery was, in these travelogues, a national issue rather than a regional one.

O'Connor argues that understanding British conceptions of the North South divide in the decades before the 
conflict is crucial to explain British opinions of the Civil War. The book is able to give a nuanced understanding of the prevailing British pro-Confederate, or anti-Union sentiment at the start of the conflict. Simply focusing on British attitudes during the four years of the Civil War, O'Connor suggests, gives the impression that Britons were more committedly pro-Southern during the conflict than is accurate. The British image of the North, built up in the three decades before the war, as ethnically and economically distinct from the South, as well as deeply racist towards African-Americans, and without any real commitment to abolition, made supporting the Union cause in Britain difficult. The two regions were, in British writing about the United States, so different, and neither region was committed to abolition. American Sectionalism shows how British writers failed to understand why the two regions should be compelled to remain united, given these differences. Longstanding perceptions of America regional differences meant that many in Britain favoured a pro-Confederate view of the war. Ultimately O'Connor agrees with scholars like Richard J.M. Blackett that distaste for both sides of the conflict was common in Britain. However, O'Connor explains this distaste for both sides of the Civil War in a longer time frame and in better detail than has been done previously.

American Sectionalism's most notable contribution to the study of British images of the American Civil War is the re-evaluation of how British observers understood U.S. regional divisions. British travellers to the United States did not see a clear North-South divide, rather most travellers cut the country into three sections: the South, New England, and the Mid-Atlantic States in between. All three of these regions contained, for British writers like Charles Dickens and Harriet Martineau, different economic, political and above all cultural dynamics. The South was, for British travellers, an agricultural slave society, but a paternalistic one. British visitors to the South, in the wake of economic stagnation in the West Indies after the 1832 emancipation, were sceptical of the benefits of immediate manumission. Nearly all writers of travelogues on the South agreed that slavery was a moral evil, but also argued immediate abolition would create greater problems. British writers further admired the 'aristocratic' society of the American South. Southern planters were, in these travelogues, ethnically similar to Britons and had created a society to comparable to Britain's landed gentry. On trade even the great liberal reformer Harriet Martineau agreed with Southerners' opposition to tariffs, though she thought slavery was the cause of the region's economic problems rather than protectionism. Overall, O'Connor presents a very charitable British image of the American South as politically and culturally similar to the United Kingdom.

British writers, according to O'Connor, saw New England as a distinctive region with a homogenous population, ethnically similar to Britons. Travellers to the United States recorded the better treatment free African-Americans received in New England, as well as the firmer commitment to abolitionism in the region. However, these same writers also thought the region staid and puritanical. New Englanders were the roundheads to the South's cavaliers. One traveller, Charles Augustus Murray, compared the South and New England to England and Scotland, both were British but of contrasting temperaments.

The final, and in many ways most hated by British travellers, section of the United States examined in American Sectionalism is the Mid-Atlantic States. If the South and New England were ethnically homogeneous and related to Britons, at least in the writings of transatlantic travellers, then states like New York and Pennsylvania appeared in these travelogues as an ethnic hodgepodge. British visitors described urban centres in these states, particularly New York City, as Irish metropolises. Politics in these states was dominated, according to British travel guides, by Anglophobic demagogues who at every election attempted to curry favour with the Irish electorate. Citizens of the Mid-Atlantic States were, according to these guides, uninterested in racial equality and deeply suspicious of abolitionism. To be fair, as O'Connor points out, British abolitionists often used slavery to tar the entire American system of government and were thus generally unpopular. Hence, the poor treatment received by British abolitionists was possibly more about their nationality than their politics. The Mid-Atlantic States and New England were also the centres of American protectionism. This resistance to free trade, combined with Northern capitalists' involvement in the slave trade, showed for British travellers the region's hypocrisy over slavery. Northerners might disagree with the institution, nevertheless they still profited from it. 
To make this argument O'Connor mostly uses the vast amount of travel, and other popular literature, on the United States in mid-19th century Britain. The sheer number of these travelogues and the diversity of their authors allow the book to make broad claims about British understandings of American sectionalism. Popular travelogues like Fanny Trollop's 1832 Domestic Manners of the Americans, and Charles Dickens' 1842 American Notes For General Circulation are used, but also more political works by ardent reformers like John Silk Buckingham and Harriet Martineau appear. In the final two chapters, focused on the Civil War, O'Connor makes excellent use of Confederate propagandists Henry Hotze and James Spence's output to show how British conceptions of sectionalism could bolster support for South. Overall the book's use of travelogues feels very comprehensive.

O'Connor adeptly uses this new division of the United States to argue that British ideas about the politics of slavery in the United States, and the cultural differences between North and South, made British sympathy for the Confederacy easy. American Sectionalism makes much of William Gladstone's Newcastle speech, in which he endorsed the CSA mere days before news of the Emancipation Proclamation reached Britain. Gladstone was not the Confederate pro-slavery apologist that Northerners and some historians have claimed him to be. Rather O'Connor argues that Gladstone's position was rational given the British understanding of American politics. If one believed, as O'Connor shows many Britons did, that there was no national commitment to abolition, and clear cultural and ethnic differences between North and South, then support for the CSA, or at least belief like Gladstone's that Southern independence and nationhood was a fait accompli, was logical.

O'Connor's conclusions differ somewhat from recent work on the conflict most notably Don Doyle's The Cause of All Nations: An International History of the American Civil War.(2) While Doyle sees the Union cause as one that united European Liberals behind the justice of republicanism and abolition, O'Connor's examination of a much longer period of time shows that lasting images of the United States could morph into an acceptance of Southern independence. American Sectionalism does not argue for a full throated British support for the Confederacy, and is on this question very much in line with work like Divided Hearts: Britain and the American Civil War by Richard J.M. Blackett, or Martin Crawford's The Anglo-American Crisis of the Mid-Nineteenth Century: The Times and America, 1850-1862.(3) Both books suggest a popular distaste for both sides. O'Connor, rather, argues that by using pre-existing British ideas about American sectionalism one can see how Britons might have distaste for the Union, and a tepid acceptance of Confederate independence.

American Sectionalism is an fine addition to the growing number of books that seek to examine politics and ideas about the United States in terms of popular political subjects. Much like the recent work on free trade, and the United States governmental model in Italy, American Sectionalism does an excellent job linking intellectual history with politics and culture. As O'Conner himself deftly points out, the book is situated to stand between the work of transatlantic political historians on the period like Duncan Andrew Campbell, and intellectual historians like Leslie Butler. This positioning is effective, and by using the wide base of source materials on transatlantic travel to the United States, as well as sources from such a wide time frame O'Connor is able to make new and interesting conclusions about sectionalism and British responses to the American Civil War.

\section{Notes}

1. Marc-William Palen, The 'Conspiracy' of Free Trade: The Anglo-American Struggle over Empire and Economic Globalisation, 1846-1896 (Cambridge, 2016); Axel Körner, America in Italy: The United States in the Political Thought and Imagination of the Italian Risorgimento, 1763-1865 (Princeton, NJ, 2017). Back to (1)

2. Don Doyle, The Cause of All Nations: An International History of the American Civil War (New York, NY, 2013). Back to (2)

3. Richard J. M. Blackett, Divided Hearts: Britain and the American Civil War (Baton Rouge, LA, 
2000); Martin Crawford, The Anglo-American Crisis of the Mid-Nineteenth Century: The Times and America, 1850-1862 (Athens, GA, 1987). Back to (3)

Source URL:https://reviews.history.ac.uk/review/2227

\section{Links}

[1] https://reviews.history.ac.uk/item/295272 